\title{
Comparative Micromorphological Investigations of Red Godji Berries (Lycium barbarum L.) and Black Godji Berries (Lycium ruthenicum Murr.)
}

\author{
Serebryanaya Fatima Kazbekovna, Sekinaeva Marina Arsenovna, Denisenko Oleg Nikolaevich
}

\section{Serebryanaya Fatima Kaz- bekovna, Sekinaeva Marina Arsenovna, Denisenko Oleg Nikolaevich}

Pyatigorsk Medical and Pharmaceutical Institute-Branch of Volgograd State Medical University of Russian Ministry of Health (357532, Pyatigorsk, AV. Kalinina-11, RUSSIA.

\section{Correspondence}

\section{Serebryanaya Fatima Kazbekovna}

Department of Pharmacognosy and botany, Pyatigorsk Medical and Pharmaceutical Institute, a Branch of Volgograd State Medical University, RUSSIA.

Phone no : 89283776847

E-mail: f.k.serebryanaya@ pmedpharm.ru History

- Submission Date: 06-02-2018;

- Review completed: 25-04-2018;

- Accepted Date: 26-06-2018

DOI : 10.5530/pj.2018.5.153

Article Available online http://www.phcogj.com/v10/i5

\section{Copyright}

(C) 2018 Phcog.Net. This is an openaccess article distributed under the terms of the Creative Commons Attribution 4.0 International license.

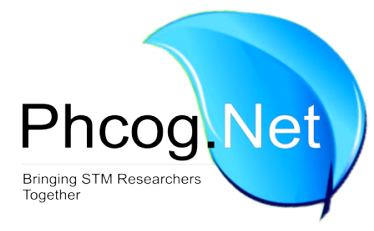

\begin{abstract}
The comparative morphological and anatomical research of the fruits and seeds of two species of the genre Lycium is conducted. An objective of this research was carrying out comparative studying of anatomical diagnostic signs of fruits of a red Godji berries (Lycium barbarum L.) and black Godjy berries (Lycium ruthenicum Murr.) for establishment of authenticity of medicinal vegetable raw materials. This work is a fragment of complex researches of plants of flora of the North Caucasus and also introduced species. Because of the conducted comparative this research the main signs allowing to carry out identification of medicinal vegetable raw materials both in integral and in the crushed look are revealed. The conducted researches can be used further for development of normative documentation on raw materials of these species.

Key words: Lycium barbarum L, Lycium ruthenicum, Micro-diagnostic features, Fruits, Seeds, Testa, Chromoplastes.
\end{abstract}

\section{INTRODUCTION}

Recently in Russia and all over world use in food of goji berries gains popularity (Lycium barbarum L.) as a source of the biologically fissile connections. In scientific literature it is possible to meet data on immunomodulatory, antioxidant, hepatoprotective, anti-diabetic and antineoplastic activity. ${ }^{1-4,10,15,21}$ Representatives of the genre Lycium, including the species included in the Pharmacopoeia of Japan and China grow naturally in Asia and Southeast Europe, traditionally are plants of traditional Chinese medicine, are applied at inflammatory processes, anemia. ${ }^{3,4,14,20}$ Antioxidant properties of berries of the species Lycium are known. Black Godjy berries (Lycium ruthenicum) is known along with red godjy berries, the area of growth of this look covers the European part of the Russian Federation, meets in the Lower Volga district, in the Caucasus, in Central Asia. Meets mainly on river valleys, it is widespread in dry places and on the semi-salted soils. Both species fall into two group of halophytes, grows on the salted soils, accumulating at the same time the significant amount of salts..$^{13,24,25,28}$

Chemical composition of goji berries is interesting, so according to literature at a research of flavonoid fraction the HPLC method revealed presence of flavonols..$^{2,5,8,19}$ Besides, the polysacharides fraction possesses the expressed antidiabetic action, at the same time researches of influence of components on the mechanism of prevention of peripheral diabetic neuropathy are conducted. Goji berries are applied at therapy of diseases of the central nervous system, including to prophylaxis of Alzheimer's disease. ${ }^{12,13}$

The received researches can be interesting further at prophylaxis of degenerative diseases of nervous system. Existence of anthocyanins, including derivants of a delphinidine is characteristic of Lycium ruthenicum (black goji berries). ${ }^{9,23}$ For both types of Lycium barbarum L. and L. ruthenicum Murr. existence of carotenoids is characteristic. ${ }^{6,8}$ Cholagogue, laxative action of fruits of a black godjy berries is characteristic. Fruits of L. ruthenicum Murr. are applied at diseases of the alimentary system and respiratory failure..$^{26,27}$

In the Russian Federation there is no normative documentation on a red goji berries (Lycium barbarum L.) and to a black goji berries (Lycium ruthenicum murr.), these plants are not brought in the State Pharmacopoeia of Russia. For use in pharmaceutical practice of new types of medicinal vegetable raw materials, work on development of indexes of authenticity and high quality for creation in the subsequent normative documentation must be carried out.

Purpose: Comparative studying of anatomical diagnostic signs of fruits of a red goji berries (Lycium barbarum L.) and black goji berries (Lycium ruthenicum Murr.) for identification, the characteristic, estab- 
lishment of authenticity of raw materials. This work is a fragment of complex researches of plants of flora of the North Caucasus and the introduced species growing in the territory of reserves and botanical gardens. ${ }^{7,17,18,22,29,30}$

Objects: Berries of a red goji berries (Lycium barbarum) introduced in the territory of a botanical garden of the Mountain State Agricultural University (MSAU) of Vladikavkaz RSO-Alania and the berries of a black goji berries (Lycium ruthenicum) picked in wild-growing flora in Apsheronsky District in the valley of the river Tugchay.

\section{RESULTS AND DISCUSSION}

The genre Lycium includes more than 90 species among which galophytes occur. Among species it should be noted those which grow mainly in Asia, treat them L. afrum, L. andersonii, L. arabicum, L. australe, L. barbarum, L. berlandieri, L. carolinianum, L. chinense, L. europaeum, L. fremontii, L. pallidum, L. ruthenicum, L. schweinfurthii, L. torreyi. ${ }^{10-11}$ Red goji berries (Lycium barbarum L.) - long-term branchy bush 2-2,5 m high of family Solanaceae. Escapes are numerous the lengthiest, thin, on the ends hanging, light yellow with short, 6-15 $\mathrm{mm}$ long, thin, usually neodeciduous lateral prickles. Prickles represent the modified shortened escapes. Kidneys are small, often individual, with silvery renal the parts hidden under bark hardly noticeable from under the cracked stalk false skin. The sheet hem is poorly noticeable, with one sheet trace. Leaves only on growth escapes, individual, other in bunches on some from the kidneys shortened, which are not developing interstices of escapes side the lateral. From above leaves green, from below glaucescent, with side veins, tightly inverse lanceolate, elliptic lanceolate or narrow and elliptic, with the blunt, sharp or pointed top and tightly clinoid basis, is insensitive passing into a scape. The sheet plate $2-3 \mathrm{~cm}$ long and $2,5-8 \mathrm{~mm}$ wide, on the dolychoblast at cultural plants reaches $6 \mathrm{~cm}$ long and $3 \mathrm{~cm}$ wide and usually has the lanceolate form. The scape is 3-5 times shorter than a plate. Flowers pale violet, on the lengthiest up reinforced pedicels 5-15 $\mathrm{mm}$ long, on 1-4 in bosoms of leaves.

Calice 4-5 mm long, campanulated, it is to the middle more deeply cut on 2-3 unequal shares, edges of shares or waves usually smooth, only on a tip felt are rarer 4-5-gear. The nimbus 11-15 mm long, funnel-shaped, with the tube considerably exceeding longwise bending in the bottom narrow cylindrical, then gradually funnel-shaped and expanded, outside of naked, is higher than attachment of stamens with a pilar and felt ring inside. Corolle is five-partite, light, pink or it is violet - pink, with more dark veins and the bases of shares. Bending shares ovoid, in the bottom quickly reduced to the basis, it is frequent with ears, on edge with infrequent cilia. Threads of stamens are attached near the middle of a tube and from the basis or a little above throughout $1-1,25 \mathrm{~mm}$ are very densely trimmed circle the lengthiest hairs. From five stamens two-three are equal to a nimbus, the others are a little shorter than it. The column is a little longer than stamens. Fruit - berry red, oblong and ovoid, blunt or sharp, 8-18 mm long, 5-10 mm wide. Blossoms from June to September. Fruits ripen in July-October. The natural area of growth of a look is limited to areas of Central China. (Figure 1) In Central Russia grows run wild mainly in the black earth belt. Grows on slopes, breaks, gardens, waste grounds of the Belgorod, Bryansk, Voronezh, Kursk, Lipetsk and Tambov regions, sometimes runs wild ${ }^{2,11,20,24-26}$

Black godji berries (Lycium ruthenicum Murr.) - a bush, 50-200 cm high with the knotty, spread wide, naked, prickly, yellow-white branches. Escapes are robust, yellow-white, seated by styliform short prickles, up to $20 \mathrm{~mm}$ long. The branches which are spread wide, bearing short leafless prickles and the numerous prickly pointed escapes. Prickles are leafless, thin, the lengthiest 3-20 mm. Ash-gray bark. Kidneys with several external flakes, shallow. Leaves are simple, gray, pulpy, almost sedentary,
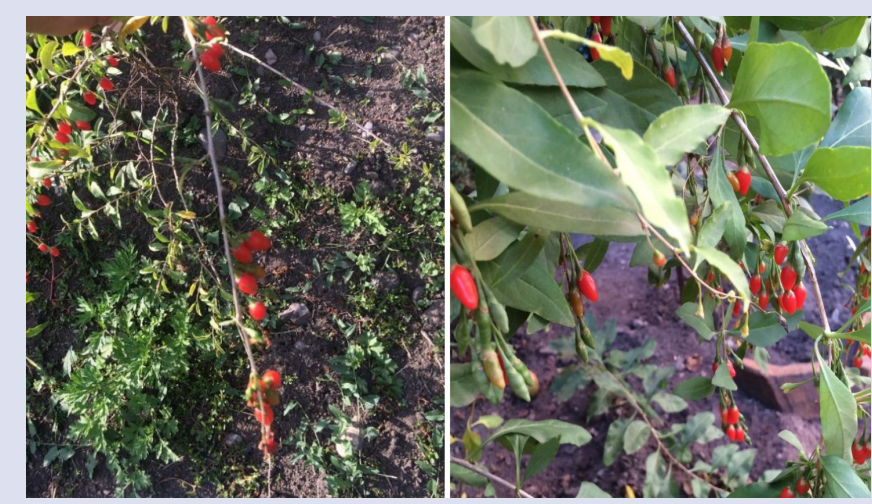

Figure 1: Appearance of a red godji berries (Lycium barbarum L.), introduced in the territory of a botanical garden of the Mountain State Agricultural University (MSAU) of Vladikavkaz RSO-Alania.

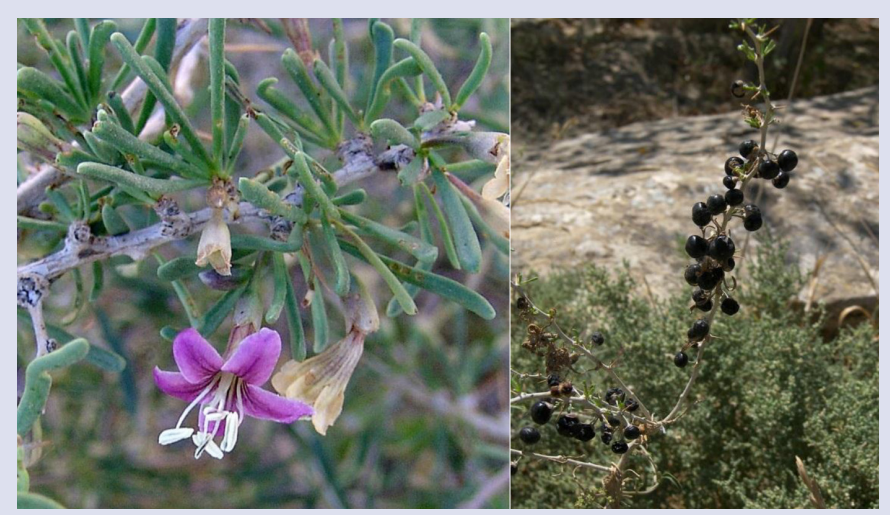

Figure 2: Appearance of a black godji berries (Lycium ruthenicum murr.) the exemplar is find in the territory of the republic Azerbaijan (Apsheronsky District).

mostly linaire, blunt, $0,5-3,5 \mathrm{~cm}$ of the lengthiest and $0,7-3 \mathrm{~mm}$ wide, strongly vary in a form.

Flowers pink, located in bosoms of leaves, simple or on 2-3 in the bunches located on both parties of prickles or rather short prickly branches on pedicels $4-8 \mathrm{~mm}$ long. The calice is campanulated, with 2-3 unequal blades, seldom unequal 5-gear, 2,5-4,5 mm long. A corolle up to $15 \mathrm{~mm}$ long, with a funnel-shaped whitish tube and oblong 4-5 the made an incision bending. Stamens unequal longwise with a little expanded and trimmed at the basis threads. Fruits are black, juicy, berries of $4-8 \mathrm{~mm}$ in the diameter, with many seeds. Seeds brown, reniform, angular, about 2 $\mathrm{mm}$ long, and 1,5-1,8 mm wide (Figure 2). Blossoms twice, in April-July, fructifies in June-October. ${ }^{2,10,25,27,31}$ The ecological confinedness to open sites, edges, a look photophilous is characteristic and unpretentious, well transfers the salted soils. Grows on sandy substrates, saline soils. . $^{13,24,25,28}$

Because of the conducted research the following morphological indexes as a form and coloring of a sheet plate and a form and coloring of fruits, a structure of seeds is studied. Results are presented in Table 1. Features of a morphological structure of fruits and seeds of two types are presented in the Figure 3.

We conducted a micromorphological research of berries of red godji berries (Lycium barbarum L.) and black godji berries (L. ruthenicum Murr.). Vegetable raw materials fixed in system ethanol 96\%-glycerin water in the ratio 1:1:1. Transversal cuts of berries (pericarpe) and a seed carried out by means of edges, carried out coloring by histochemical reactants - solution of phloroglucinol and sulfuric acid of $50 \%$ for iden- 
Serebryanaya FK, et al:: Comparative Micromorphological Investigations of Red Godji Berries and Black Godji Berries

Table 1: Comparative morphological characteristic of fruits of Lycium barbarum L. and L. ruthenicum Murr.)

\begin{tabular}{|c|c|c|}
\hline Morphological features & Lycium barbarum L. & Lycium ruthenicum Murr. \\
\hline \multirow[t]{2}{*}{ Life-form } & Bush & Bush \\
\hline & $1-2,5 \mathrm{~m}$ high. & 0,5 - $2 \mathrm{~m}$ high. \\
\hline \multirow[t]{2}{*}{ Leaves } & $\begin{array}{c}\text { Leaves are green, from below glaucescent tightly inverse } \\
\text { lanceolate. }\end{array}$ & $\begin{array}{l}\text { Leaves are gray, pulpy, almost sedentary, the mostly linear. } \\
\text { Sheet plate } 0,5-3,5 \mathrm{~cm} \text { long and } 0,7-3 \mathrm{~mm} \text { wide }\end{array}$ \\
\hline & Sheet plate $2-3 \mathrm{~cm}$ long and $2,5-8 \mathrm{~mm}$ wide & \\
\hline Fruits & $\begin{array}{c}\text { Berry, oblong and ovoid, 8-18 mm long, 5-10 mm wide, with } \\
\text { more seeds }\end{array}$ & Berry spherical, $4-8 \mathrm{~mm}$ in the diameter, with more seeds \\
\hline Coloring of fruits & Red-orange & black \\
\hline \multirow[t]{3}{*}{ Seeds } & Ocherous, & Reniform, \\
\hline & rounded reniform, & angular brown, \\
\hline & with a diameter of $2,5-3 \mathrm{~mm}$. & with a diameter of $1,5-2 \mathrm{~mm}$. \\
\hline
\end{tabular}

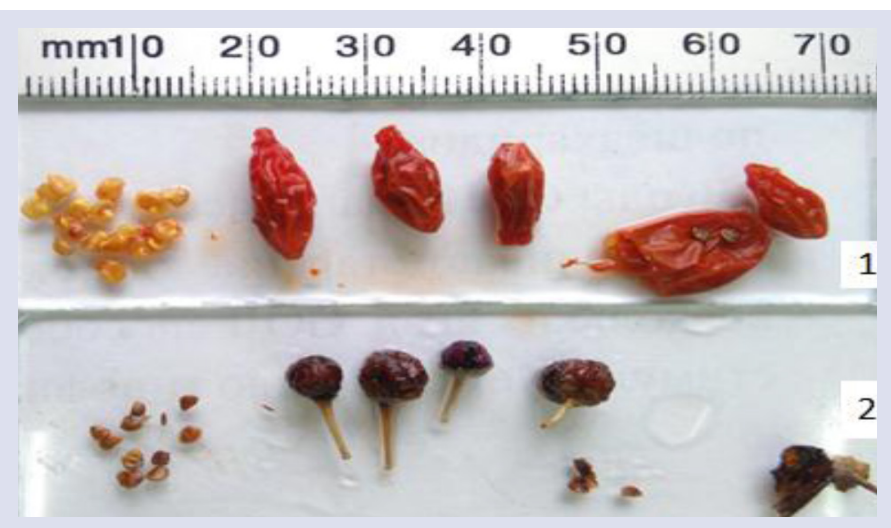

Figure 3: Morphological structure of fruits of godjy berries (1-Lycium barbarum L., 2-L. ruthenicum Murr.).
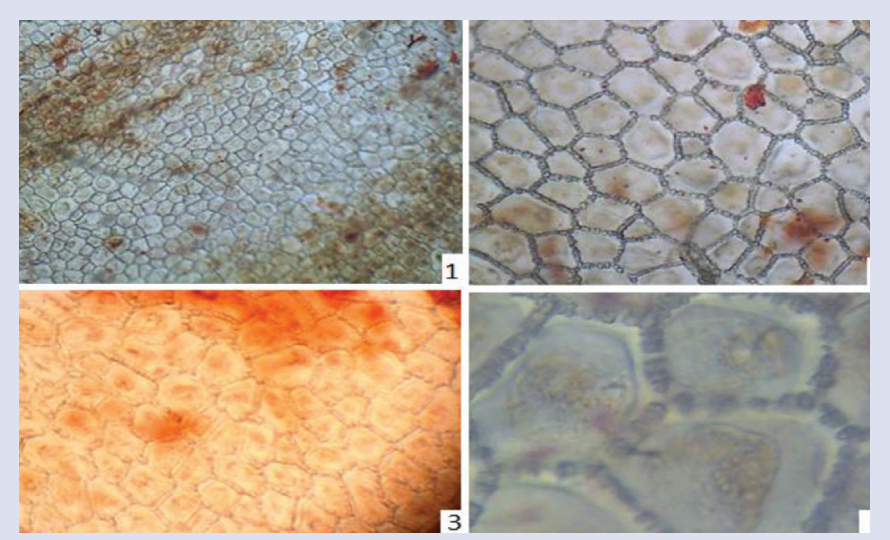

Figure 4: The structure of an exocarp of a fruit of red godji berries (Lycium barbarum L.) Exocarp cells with necklace-shaped thickenings of anticlinal walls.

1- objective magnification $\times 4$; 2,3- objective magnification $\times 10$;

4 - objective magnification $\times 40$.

tification of lignified elements. ${ }^{3}$ The received micropreparations studied by means of a microscope Biomed-2 with a DCEE MD300. The anatomic structure of fruits of a red godji berries is studied (Lycium barbarum L.), existence of a juicy pulpy pericarp, exocarp filmy, thin is characteristic of fruits, consists of one layer of cages of a rectangular and polyhedral form. The reference sign is existence of necklace-shaped thickenings

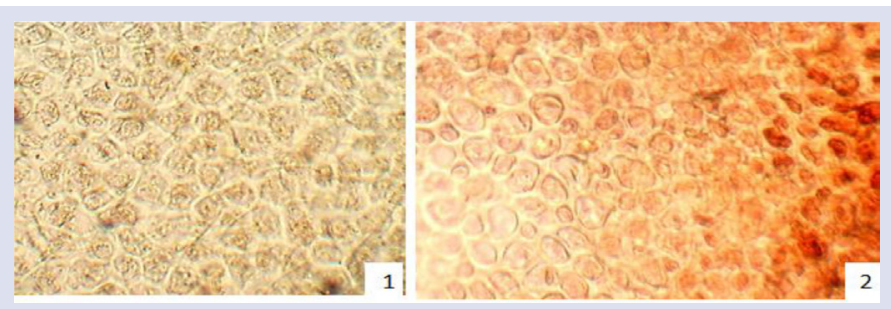

Figure 5: The structure of an exocarp of a fruit of a black godji berries (L. ruthenicum Murr.). Exocarp cells without necklace-shaped thickenings of anticlinal walls.

1-2- objective magnification $\times 4$

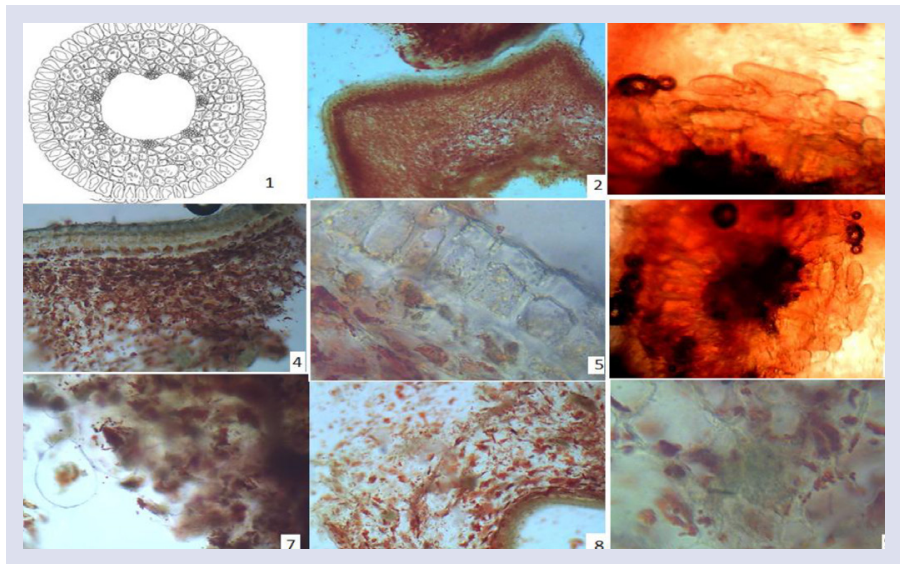

Figure 6: The structure of a pericarp of Lycium barbarum L. on a transverse section, scheme of a structure of a pericarp, 2,4- fragment of a transversal sections of a pericarp, 3,6 - stony cells (sclereids), 5-epidermal cells covered with the uniform layer of a cuticle, 7-thin-walled cells of a mesocarp with a large amount of chromoplastes, 8-9 - collateral vascular bundles and endocarp cells. 1,2- objective magnification $x 4$; 3,6,8- objective magnification $\mathrm{x} 10 ; 5,7,9$ - objective magnification $\times 40$.

of anticlinal walls of cages of an exocarp (Figure 4). For an exocarp of fruits of black godji berries (L. ruthenicum Murr.) existence of cages of an izodiametrical form with direct anticlinal walls without thickenings is characteristic. (Figure 5).

On a transversal section of a pericarp of a red godjy berries (Lycium barbarum L.) exocarp cells have a rectangular form, are covered with the uniform layer of a cuticle. Mesocarp cells thin-walled, contain the significant amount of chromoplastes (Figure 8). Between parenchyme cells of a mesocarp are well noticeable the located joints of stony cells in a look 


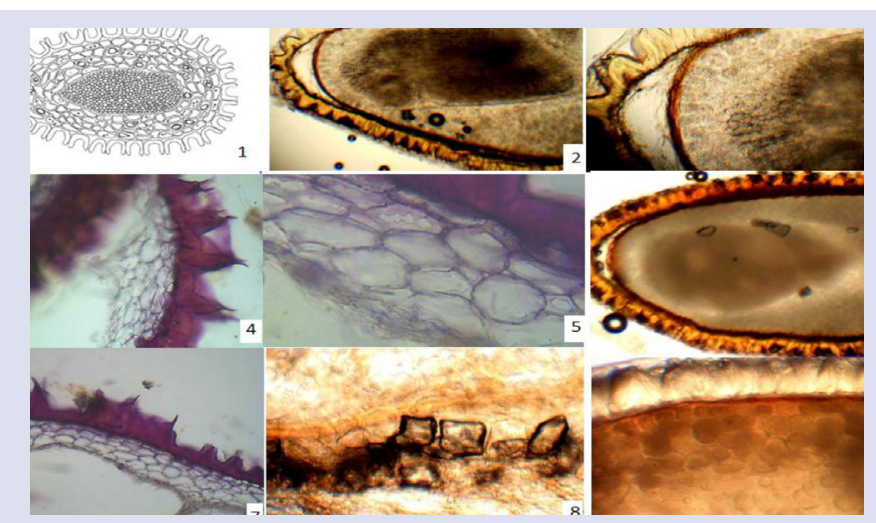

Figure 7: The Structure of a pericarp and a seed of $L$. ruthenicum Murr. on a transverse section, 1 scheme of a transversal cut, 2,3,6 - fragments of a transversal cut of a seed, 4,5,7-specialised cells with reinforced lignified walls, 5 - sclereids, 8 - calcium oxalatum crystals in parenchym cells, 9 - aleuron cells and endosperm cells (amydon). 1,2,6 - objective magnification $\times 4 ; 2,3,6,9$ - objective magnification $\times 10 ; 5,8,9$ - objective magnification $\times 40$.

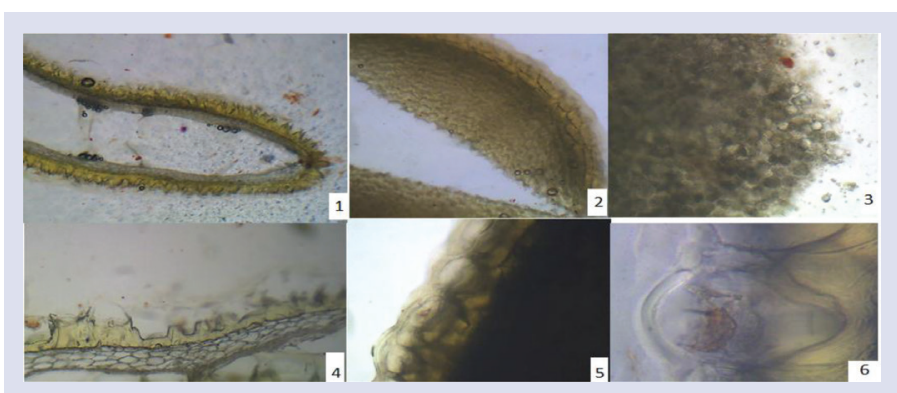

Figure 8: The Structure of a pericarp and a seed of Lycium barbarum L. on a transverse section, 1,4 - elements of a pericarp, 2 - a fragment of a transversal section of a seed, 5,6 - cages with reinforced lignified walls, 3 endosperm cells with a great many starchy and the aleuron of grains.1,2,6 - objective magnification $\times 4 ; 2,3,6,9$ - objective magnification $\times 10 ; 5,8,9$ objective magnification $\times 40$.

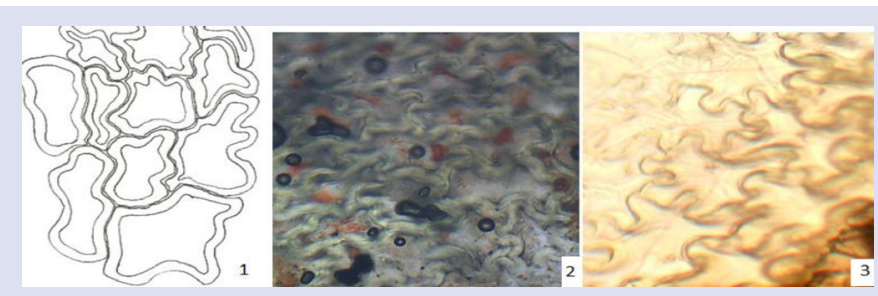

Figure 9: Structure of a seed testa of L. barbarum L. $(1,2)$ and L. ruthenicum Murr.(3).

brachysclereids the oval or slightly extended form. Closer to the central area 7-8 vascular bundles of collateral type with shallow conductive elements (Figure 6) are well distinguishable.

When studying an anatomic structure of elements of a pericarp and seeds of $L$. ruthenicum Murr. on a transverse section the following blocks are found, the seed peel is presented by one layer of thick-walled cages with strongly lignified walls. When coloring by solution of phloroglucinol and sulfuric acid observed pink-violet coloring that testa to the maximal degree of a lignification. Under cells of a seed peel the lying sclereids of the extended form are located separately. The trace located cells with aleuron grains and endosperm cells, rich with starchy grains (Figure 7).

There was a wish to pay special attention to an anatomic structure of a seed testa. Existence of cells with strongly sinuous anticlinal walls and evenly reinforced cell-like wall (Figure 9) is characteristic of both studied species.

\section{CONCLUSION}

Because of the conducted comparative this research we revealed the main signs allowing to carry out identification of medicinal vegetable raw materials both in integral and in the crushed look. The conducted researches can be used further for development of normative documentation on raw materials of a red godjy berries (Lycium barbarum) and the black godgy berries (L. ruthenicum).

\section{REFERENCES}

1. Gan L, Zhang SH, Liu Q, et al. A polysaccharide-protein complex from Lycium barbarum upregulates cytokine expression in human peripheral blood mononuclear cells/ L. European J of Pharmacology. 2003;471(3):217-22.

2. Amagase $H$, Farnsworth NR. A review of botanical characteristics, phytochemistry, clinical relevance in efficacy and safety of Lycium barbarum fruit (Goji) Food Research International. 2011;44(7):1702-17.

3. Altintas A, Kosar M, Kirimer N, Baser K, Demirci B. Composition of the essential oils of Lycium barbarum and L. ruthenicum fruits. Chem Nat Compd. 2006;42:24-5. 10.1007/s10600-006-0028-3.

4. American Herbal Pharmacopoeia: Botanical Pharmacognosy - Microscopic characterization of botanical Medicines. Edited by Roy Upton. 2013:468.

5. Wu T, Lv H, Wang F, Wang Y. Characterization of Polyphenols from Lycium ruthenicum Fruit by UPLC-Q-TOF/MS(E) and Their Antioxidant Activity in Caco-2 Cells. J Agric Food Chem. 2016;64(11):2280-8. doi: 10.1021/acs.jafc.6b00035. Epub 2016 Mar 10.

6. Liu Y, Zeng S, Sun W, Wu M, Hu W, Shen X, Wang Y. Comparative analysis of carotenoid accumulation in two goji (Lycium barbarum L. and L. ruthenicumMurr.) fruits. BMC Plant Biology. 2014;14(1):269.

7. Serebryanaya FK, Orlov AN, Konovalov DA. Nasuhova NM. Comparative Mor phological and Anatomical Research of Leaves 6 Sorts of Laurels Noble (Laurus Nobilis L.), Growing in the Conditions of an Introduction in the Nikitsky Botanical Garden. Pharmacognosy Journal. 2018;10(1):172-8. DOI:10.5530/pj.2018.1.29

8. Islam A, Yu X, Badwal TS, Xu B. Comparative studies on phenolic profles, antioxidant capacities and carotenoid contents of red goji berry (Lycium barbarum) and black goji berry (Lycium ruthenicum). Chemistry Central Journal. 2017;11(1):59. DOI 10.1186/s13065-017-0287-Z.

9. Wang Z, Yan Y, Nisar T, Zou L, Yang X, Niu P, et al. Comparison and multivariate statistical analysis of anthocyanin composition in Lycium ruthenicum murray from different regions to trace geographical origins: The case of China. Food Chem. 2018;246:233-41. doi: 10.1016/j.foodchem.2017.11.030. Epub 2017 Nov 10.

10. Elan MS. Lycium barbarum L. Solanaceae. Laboratories. http://www.alkemist com.

11. Hitchcock, Charles Leo. A Monographic Study of the Genus Lycium of the Western Hemisphere. Annals of the Missouri Botanical Garden. 1932;19(2/3):179-348. Hu X, Qu Y, Chu Q, Li W, He J. Investigation of the neuroprotective effects of Lycium barbarum water extract in apoptotic cells and Alzheimer's disease mice. Mol Med Rep. 2017. doi: 10.3892/mmr.2017.8310.

12. Liu Y, Song Y, Zeng S, Patra B, Yuan L, Wang Y. Isolation and characterization of a salt stress-responsive betaine aldehyde dehydrogenase in Lycium ruthenicum murr. Physiol Plant. 2018. doi: 10.1111/ppl.12669.

13. Japanese Pharmacopoeia. Lycium Fruit, Lycii Fructus. Official monograph In Japanese Pharmacopoeia. (Fifteenth Edition). 2006;1315. http://jpdb.nihs.go.jp/ jp15e/JP15.pdf.

14. Lycium (Lycium barbarum). Cassileth B. Oncology (Williston Park). 2010;24(14):1353

15. Liu SY, Chen L, Li XC, Hu QK, He LJ. Lycium barbarum polysaccharide protects diabetic peripheral neuropathy by enhancing autophagy via mTOR/p70S6K inhibition in Streptozotocin-induced diabetic rats. J Chem Neuroanat. 2017.- pii: S0891-0618(17)30223-5. doi: 10.1016/j.jchemneu.2017.12.011.

16. Serebryanaya FK, Sharenko OM, Serkov MA. Morphological and anatomical investigations of Vicia truncatula Fish. ex Bieb. Pharmacognosy Journal 2015;7(3):205-9. DOI:10.5530/pj.2015.3.10.

17. Serebryanaya FK, Nasuhova NM, Konovalov DA. Morphological and Anatomica Study of the leaves of Laurus nobilis L. (Lauraceae), growing in the Introduction of the Northern Caucasus region (Russia). Pharmacognosy Journal. 2017;9(4):519-22. DOI:10.5530/pj.2017.4.83.

18. Tripodo G, Ibáñez E, Cifuentes A, Gilbert-Lopez B, Fanali C. Optimization of 
pressurized liquid extraction by response surface methodology of Goji berry (Lycium barbarum L.) phenolic bioactive compounds. Electrophoresis. 2018. DOI:10.1002/elps.201700448. [Epub ahead of print] PMID:29314152.

19. Pharmacopoeia of the People's Republic of China. 2005;5(1):234.

20. Lin L, Jin L, Li XJ, Cui ZJ, Wang ZH, Ma Y. Survey and protective utilization of Lycium ruthenicum resources distributed in middle and lower reaches of Heihe river. 2017;42(22):4419-25. doi: 10.19540/j.cnki.cjcmm.2017.0194. Chinese. PMID: 29318845

21. Sekinaeva MA, Serebryanaya FK, Denisenko ON, Lyashenko SS. The study of anatomical features of the herb Lycium (Lycium barbarum L). Advances in Current Natural Sciences Modern Problems of Science and Education. 2015;9(2)231-5.

22. Zeng S, Wu M, Zou C, Liu X, Shen X, Hayward A, et al. Comparative analysis of anthocyanin biosynthesis during fruit development in two Lycium species. Physiol Plant. 2014;150(4):505-16. 10.1111/ppl.12131.

23. Valyagina - Malyutina E.G. Trees and bushes of a midland of the European part of Russia. The illustrated determinant/ Ed. by T.E. Teplyakova. - M.: KMK association, 2012;420-1.

24. Gubanov IA, Kiselyova KV, Novikov VS, Tikhomirov VN. The illustrated determinant of plants of Central Russia. 2004;3:166
25. Budantsev AL, Lesiovskaya EE. Wild-growing useful plants of Russia/ - SPb.: SPHFA publishing house. 2001;540.

26. Vegetable resources of the USSR. Flowering plants, their chemical composition and use. - Leningrad: Science. 1985;1:245.

27. Rodionenko GI, S.Ya. Sokolov Trees and bushes of the USSR". Volumes, wildgrowing, cultivated and perspective for an introduction/. 1962;6:97.

28. Sekinayeva MA, Serebryanaya FK, Denisenko ON, Liashengko SS. Studying of anatomic signs of a grass of red godgy berries (Lycium barbarum L.). Achievements of the Modern Natural Sciences. 2015:9(2):231-5. URL:https://naturalsciences.ru/ru/article/view? id=35566.

29. Serebryanaya FK. Ecological and botanical researches of perspective resource species of flora of the North Caucasus//Collection of scientific works. The Volgograd state medical university, the Pyatigorsk medico-pharmaceutical institute - branch of state-funded educational institution of higher education "Volgograd state medical university" of the Ministry of Health of the Russian Federation. Pyatigorsk. 2014;77-83.

30. Litvinskaya SA, Murtazaliyev RA. Flora of the North Caucasus: Atlas continuant - M.: Fiton XXI, 2013;641.

\section{ABOUT AUTHORS}

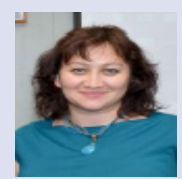

Serebryanaya Fatima Kazbekovna: Candidate of Pharmaceutical Sciences, Associate Professor, Department of Pharmacognosy and Botany of Pyatigorsk medical-pharmaceutical Institute - branch GBOU VPO Volggmu Ministry of health of Russia, RUSSIA. Ecological and botanical station Pyatigorsk of Botanical institute of Russian Academy of sciences, 197376, Saint-Petersburg, Prof. Popova av. 2, RUSSIA. Research interests: Study of the flora of the Caucasian Mineral Waters, micromorphologic study of plants of the Alpine and subnival zones of the zones of the Central Caucasus.

\section{SUMMARY}

- The comparative morphological and anatomical research of the fruits and seeds of two species of the genre Lycium is conducted. An objective of this research was carrying out compar-ative studying of anatomical diagnostic signs of fruits of a red Godjy berries (Lycium barbarum L.) and black Godjy berries (Lycium ruthenicum Murr.) for establishment of authenticity of medicinal vegetable raw materials. This work is a fragment of complex researches of plants of flora of the North Caucasus and also introduced species. Because of the conducted comparative this research the main signs allowing to carry out identification of medicinal vegetable raw materials both in integral and in the crushed look are revealed. The conducted researches can be used further for development of normative documentation on raw materials of these species.

Denisenko Oleg Nikolaevich: Doctor of Pharmaceutical Sciences, Professor, Department of Pharmacy of Pyatigorsk Medical-Pharmaceutical Institute - Branch GBOU VPO Volggmu Ministry of Health of Russia, RUSSIA. Research interests: Phytochemistry, Pharmacognosy.

Sekinaeva Marina Arsenovna: Postgraduate Student at the Chair of Pharmacy, Pyatigorsk Medical-pharmaceutical Institute - branch GBOU VPO Volggmu Ministry of Health of Russia, RUSSIA. Research interests: Phytochemistry, Pharmacognosy.

Cite this article: Serebryanaya FK, Sekinayeva MA, Denisenko ON. Comparative Micromorphological Investigations of Red Godji Berries (Lycium barbarum L.) and Black Godji Berries (Lycium ruthenicum Murr.). Pharmacog J. 2018;10(5):911-5. 